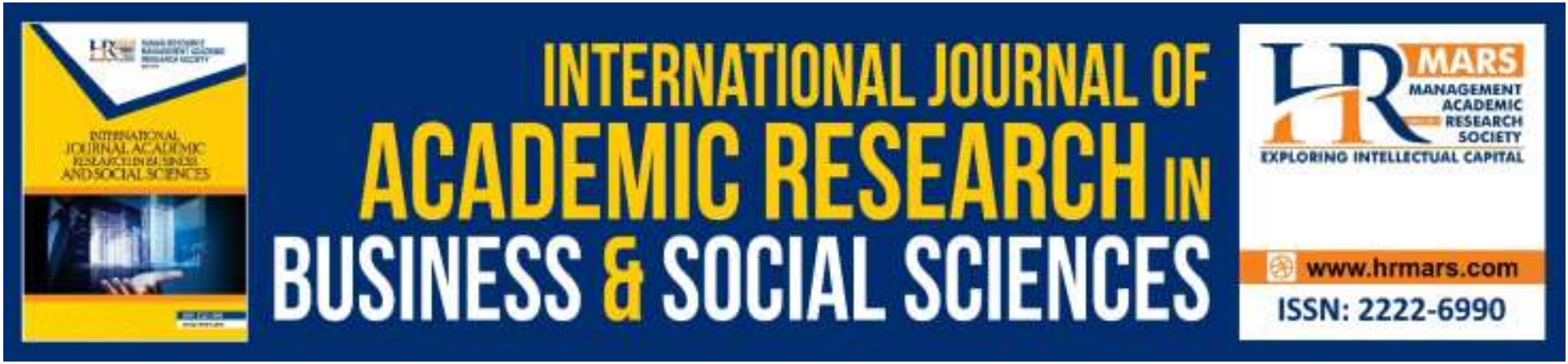

\title{
Good Leadership and Good Governance in Nigeria: An Islamic Perspective
}

Badirudeen Abdulganiyu, Ndagi Alhaji Gbate, Safiya Ismail Kaita

To Link this Article: http://dx.doi.org/10.6007/IJARBSS/v9-i8/6233

DOI: $10.6007 /$ IJARBSS/v9-i8/6233

Received: 04 June 2019, Revised: 26 June 2019, Accepted: 24 July 2019

Published Online: 08 August 2019

In-Text Citation: (Abdulganiyu, Gbate, \& Kaita, 2019)

To Cite this Article: Abdulganiyu, B., Gbate, N. A., \& Kaita, S. I. (2019). Good Leadership and Good Governance in Nigeria: An Islamic Perspective. International Journal of Academic Research in Business and Social Sciences, 9(8), 173-183.

Copyright: (C) 2019 The Author(s)

Published by Human Resource Management Academic Research Society (www.hrmars.com)

This article is published under the Creative Commons Attribution (CC BY 4.0) license. Anyone may reproduce, distribute, translate and create derivative works of this article (for both commercial and non-commercial purposes), subject to full attribution to the original publication and authors. The full terms of this license may be seen

at: http://creativecommons.org/licences/by/4.0/legalcode

Vol. 9, No. 8, 2019, Pg. 173 - 183

http://hrmars.com/index.php/pages/detail/IJARBSS

JOURNAL HOMEPAGE

Full Terms \& Conditions of access and use can be found at http://hrmars.com/index.php/pages/detail/publication-ethics 


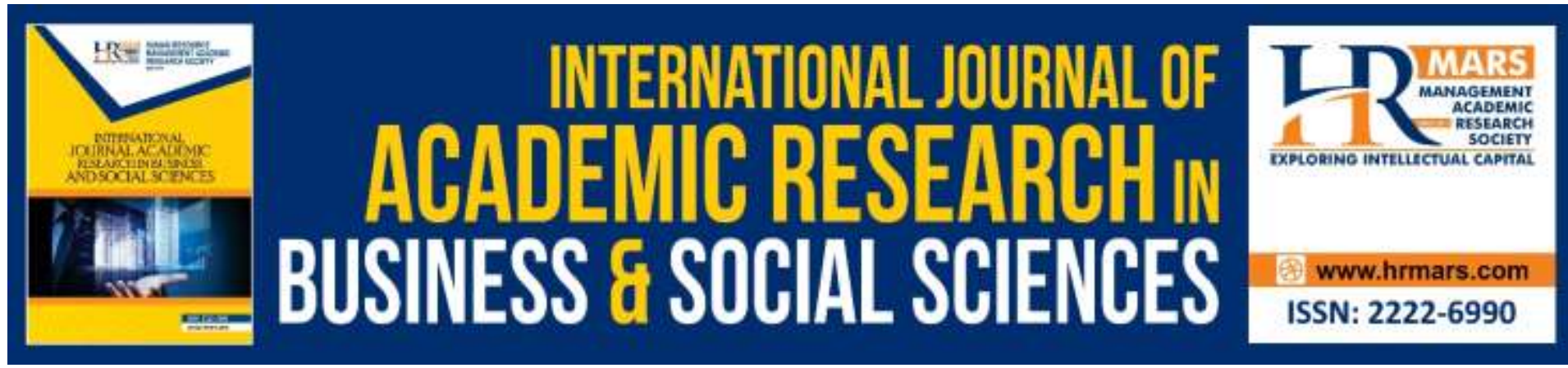

\title{
Good Leadership and Good Governance in Nigeria: An Islamic Perspective
}

\author{
Badirudeen Abdulganiyu, Ndagi Alhaji Gbate, Safiya Ismail \\ Kaita \\ Department of Islamic Studies, F.C.T. College of Education, Zuba \\ Email: badirudeenabdulgaiyu088@gmail.com,ndagigbate@gmail.com
}

\begin{abstract}
Nigeria, as a nation since her independence has been facing with challenges of leadership and good governance. It has become a phenomenon that has caused set back to the nation's development. The genes of this is that since independence majority of those who have been at the hem of her affair as leaders lack the qualities that take to be effective, efficient and productive leader. Islamviewsevery leader in society as Allah's vice-gerence and they were accountable for their actions meaning that a man is a leader in his home and he is responsible for his family, a wife is responsible for her home, the same way a leader in the society is responsible for his people. A mantle of leadership in Islam is consideredasl badah (worship) in which Allah commandevery leader be truthful and just to their people as He prohibits injustice and oppressor to them. It is against this purview that this paper examines good leadership and good governance in Nigeria: An Islamic perspective. The paper discusses concept of leadership, qualities of a leader and good governance, the paper however concludes thatfor this country to move forward, leaders at all level should stand firm to do the right thing and give selfless service rather than selfish and leap services. The paper therefore recommends among other things that leaders should imbibe the culture of piety, sincerity and accountability while in office.
\end{abstract}

Keywords: Good Leadership, Good Governance and Islam

\section{Introduction}

Nigeria is blessed in term of human and material resources and these brought her to the central focus of other nation most especially African Continent. She is refer to as the giant of Africa not in term of population but because of natural endowment natural deposits and fast land that are good for agriculture across her region. Over the years crude oil had been major source of her revenue even though present administration is trying to diversify the economy of the country to agro-economy. The country isstill remain underdeveloped not because it lack the potential to develop but it is due to the fact that the country lacks good leaders who are visionary and purposeful in driving the nation to achieve the developmental goals. It is glaring that the country in her fifty seven years of independence has not form her way to 
achieve developmental goals, and the possibility of the country's development might be narrow if it is still battling with the right way in which people are being selected or elected into the mantle of leadership. Islam set a standard which one can be used in selecting leaders as it set standard for good governance. A post of responsibility in Islam is consider as trust (Amanah) which is entrusted to the person occupying that post, such position of responsibility must not be betrayed that is why Allah enjoys every leader to do justice and fairness to their subjects.

\section{Conceptual Clarification}

Leadership has been given different connotation by different authors and scholars in different field and this make it to be difficult to settle for a single definition. To a lay man leadership may be referred to one who has ability to influence other in his society to achieve common goal. Hornby(2010 P:884) describe leader as "a person who lead a group of people especially head of a country, an organization, political or spiritual leader" Chaturved (2006 P:170) viewed leadership as ability to lead others. To lead means to guide, to direct, to cause to move in a direction. Leader means state of being lead or being first. It is an act of being led by means of which one spear-head or ahead of others. Therefore leadership is a state of being a leader (Chambers, 2004 P:408-409). Leadership in any institution be it political, region or social institution as a concept focusing the process and outcome of that institution. Leadership in Arabic language referred toRais) (رئيسmeaning, president as in president of a nation or association, head as in head of states, community, family etc. Chief; as in chief of community or village, or Chief executive of organization or institution boss, principal or superior officer. It is also referred to Qiyada (قيادة)which means Chief as in Arm Chief or Community Chief all are referred to as Khalipha(successor) (Farah, Said, Karim and Edward 2006).In the Qur'an it is considered as the position of authority to direct or guide affairs of the people under them.

ياداود إنا حعلنك خليفة في الآرض فاحكم بين الناس بالحق...

"O Daud (David): Verily We have placed you as successor on the earth; so you

judge between men in truth (and justice)"...(Q38:26)

وهو الذى جعلكم خلاخف فى الارض ورفع بعضكم فوق بعض درجات ليبلوكم فى ما اتاكم

"And it is He Who has made you (His) agent interiors of the earth; He raised you in ranks, some above others; that Hemay try you in the gift He has given you..." (Q6:165)

Leadership position in respect of the above verses is an act of directing, guiding, ruling or over seeing other people's affairs, the position either by election, selection or enforcement they are representative of Allah on earth. Such position is Allah grace bestowed on whoever assumes that responsibility and they are accountable to Him. It is in this regard that Ali (2009) mentioned that "Khalifa" means "successor, heir or inheritor that is, one who has the ultimate ownership after the president, possessor, to whom a life-tenancy has been given by the owner when he has pass away" ( $P$ :399). A leader is a person who assumes the position of authority directing or guiding others in a right direction such person is answerable to Allah (S.W.T)

\section{Qualities of a Good Leader}

Therefore, in selecting good leader the following qualities is expected thus:

\section{Al-IkLAS (Sincerity)}


A good leader is expected to undertake this responsibility for the sake of Allah, he should not look at the material life or what he will receive from the people, and he should see it as fulfilling the commandment of Allah (S.W.T) and as what Prophet order us to do.In this regard Qur'an says:

$$
\begin{aligned}
& \text { إنما نطعمكم لوجه الله لا نريد منكم جزاء ولا شكور } \\
& \text { “(Saying) we feed you seeking Allah's countenance only. We seek for no } \\
& \text { reward nor thank from you” (Q76:9) }
\end{aligned}
$$

The narration of Abu Musa says

$$
\begin{aligned}
& \text { اقبلتإلى النبى صلى الله عليه وسلم ومعى رجلان من الاشعربين احدهما عن يميني والاخر عن يساري فكلاهما }
\end{aligned}
$$



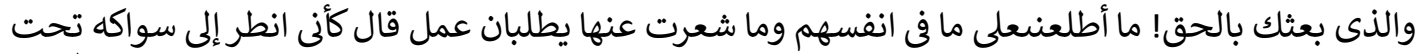

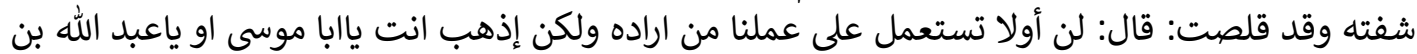



"I came to the Prophet (P.B.H) with two men of aA'sh'aris, one on my right and one on my left, both of them asked for the position of authority. The Prophet (P.B.H) was using a siwak (tooth stick) and he said: What are you saying O Abu Musa (or Abdulla bin Qais)? I said: "by the one who had sent you with the truth that they did not tell me what was on their mind and I did not realize that they were going to ask for position of authority. He said: It is as if I can see his Siwak (took stick) between his lips. He said: we will never appoint to this work those who want it rather they should go, O Abu Musa (or Abdullah bin Qais) and he sent him to be in charge of yemen..." (Muslim Vol.5:4718)

The above narration shows people who look for position of authority by all means are not sincere in their mind neither do they have interest of their people rather than it is for their selfish reason or to derive personal pleasure that is why the Prophet deny the two people request for position of authority. This is a typical behavior of our politicians who look for position of authority for their personal interest not for the interest of the masses. There a leader is require to be sincere person who stand for the interest of the lead

\section{Accessibility to Hissubjects}

A good leader must be accessible to all hisSubjects; he supposed not to accept special privilege from noble or wealthy ones, but he should treat them equally. He should not be influenced by any condition in dealing with the citizen. Leaders should not allow any consideration in dealing with his subjectsmost especially in an heterogeneous society like Nigeria so as not to cause any division and hatred among them, and this may lead to loose of confidence of some of his subjects. It is when the subjects are free to their leaders that he knows their problems. However accessibility of aleader goes a long way in solving societal problems, because it give a wide range of consultation between the leader and the lead.it is when followers have confidence in the leader that they will always consider him as trustworthy and reliable leader as mentioned in the Qur'an.

$$
\begin{aligned}
& \text { وشاورهم فى الامر... } \\
& \text { “...And consult them in affairs" (Q3:159) }
\end{aligned}
$$




\section{Good Model}

A good leader must be a role model to their subjects. This means that the leader should be exemplary to his subjects, socially, morally and spiritually, and he should exhibit discipline habit to his followers, his words must not contradict his character or action. He should be the first to obey religious rules and regulations; he should try as much as possible to avoid unlawful acts because the entire society rely on him, any misconduct from the leader may result to spoiling the entire society as observed from the Qur'an

$$
\text { لقد كن رسول الله أسوة حسنة .... }
$$

"Indeed in the Messenger of Allah you have a good example to follow"

(Q33:21)

\section{Piety (Taqwa)}

It is a popular saying that the beginning of wisdom is piety therefore every leader is expected to fear Allah and demonstrate that in their actions since they are to be exemplary to their followers this is in line with Qur'an

$$
\begin{aligned}
& \text { "يايها الذين sامنواتقوالله وقولوا قولا سديدا" } " \text { "O you who believe! Keep your duty to Allah } \\
& \text { and fear Him, and speak (always) the truth" }
\end{aligned}
$$

\section{Truthfulness}

A Leader must be truthful to his followers, he should bare it in mind that the affair of his followers is entrusted to him, he must not betrayed them, he should keep to his promised as mentioned in the Qur'an

"يايها الذين ءامنوالم تقولون مالا تفعلون, كبرمقتا عند الله انتقولوا ما لا تفعلون" Why do ل

"O you believe! Why do you say that which you do not do?

Most hateful it is with Allah that you say that which you do not do."

It is a common practice among politician in Nigeria to make series of promise without fulfilling it instead when they get to power they act contrary to the promise and they toy with the public trust giving to them. It is not surprising that prophet Mohammad said:

$$
\text { "والله ! لا تاخذ احد منكم منها شيئا بغير حقه الا لقى الله تعالى بحمله يوم القيامة" }
$$

"...By Allah! No one of you take something from it unlawfully but he will meet Allah, Exalted is $\mathrm{He}$, on the day of resurrection..."

So also Qur'an says:

$$
\text { والعصر, ان الانسان لفي خسر, إلا الذين أمنوا وعنل الصالحات وتواصو بالحق وتواصوا بالصبر. }
$$

"By (the token of) time (through the ages)

Verily man is in loss except such as (those who) have faith

And (join together) in the mutual teaching of truth and of

\section{Leniency}

$$
\text { patience and constancy (Q103:1-3) }
$$

A good Leader must be lenient with his Subjects because when a leader is mean, severe or cause harsh-hearted he would cause many of his followers to turn away from him Qur'an says:

$$
\text { فبما رحمة من الله لنت لهم ولو كنت فظا غليظ القلب لآنفضوا من حولك فاعف عنهم واستففر لهم وساورهم في الآمر }
$$


"And by mercy of Allah you dealt with them gently and had you (Muhammad S.A.W) been severe and harsh-hearted, they would have been broken away from about you, so pass over and ask Allah's forgiveness from them and consult them in the affair" (3:159)

\section{Good Governance}

Governance may be referred to as complex set of structure and processes within an organization setting or society such may be public or private administration. It is an act, manner, office or power of governing or a state of being governed or method of government or regulation. It is comprehensive ways in which individual, an institution either public or private manages their common affair or a continuous process through which conflicting or diverse interest is accommodated and co-operative action is taken. Act of governing encompasses formal institution and regime empower to enforce complianceof the formal and informal agreement that people and institution have agreed to or perceive to be their common interest (Zainab, 2017). Governance in Islam is an act of Ibadah because it involves sacrifices and commitment to the service of others, this is why Islam sees governance as a trust. given to an individual in society to contribute to the development of such society right from the family to community and society at large. It is in this regard that Prophet Muhammad (P.B.U.H) said:

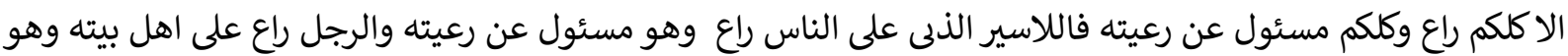

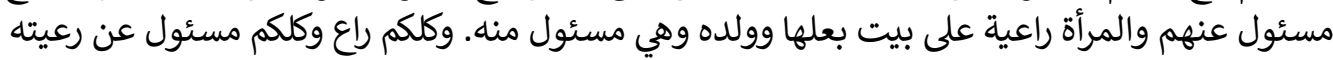

"Each of you is a shepherd and each of you is responsible for his flock. A man is a shepherd of his household and he is responsible for his flock. A woman is a shepherd of her husband's house and children and she is responsible for her flock, the slave is a shepherd of his master's wealth and he is responsible for it. Each of you is a shepherd and each of you is responsible for his flock"(Muslim, Vol.5:4724)

Good governance begins from grass root that is from home front to the larger society as it involve rule of law and justice that is built upon just and principles orderliness as well compliance of rights and responsibilities of every member of the society. The Qur'an says: يأيها الذين ءامنوا كونوا قوامين لله شهداء بالقسط ولا يجر منكم شنئان قوم الا تعدلوا أعدلو هو أقرب لتقوى وتقو الله

"O you who believe! Stand out firmly for Allah as just witness; and let not the enmity and hatred of others make you avoid justice. Be just that is dearer to piety and fear Allah..."(Q5:8)

In furtherance another verse of the Holy Qur'an says;

$$
\text { الذين إن مكنهم فى الارض أقاموا صلواة وءاتوا الزكوة وأمروا بالمعروف ونهوا عن المنكر ولله عقبة الامور }
$$

"Those (Muslim rulers) who, if we give them power in land, (they) enjoy iqamat-as-Salat (to establish the five compulsory salat (prayer)), they enjoy Al-Ma'ruf (ie Islamic Monotheism and all that are order to do) and forbid Al-Munkar (ie disbelief, polytheism and all Islam has forbidden ) (ie they make the Qur'an as the law of the country in all spheres of life) and with Allah rest the end of (all) matters (of creatures)" (Q22:41)

The good governance in Islam is place upon seven principles as mentioned by Ali (2015) they are: 

a. Rule of law
b. Khilafa
c. Accountability
d. Transparency
e. Justice
f. Equity and
g. Al-AmrbilMA'rufwanahi an-al-Munkar

\section{Rule of Law}

Good governance begins with rule of law which makes the leader accountable to Allah; that is to say Sovereignty belong to Allah not to the people. Islamic principle of rule of law is based on Sharia. The Shura are the custodian of justice and witness for Allah even when it is against them as mentioned in the Qur'an;

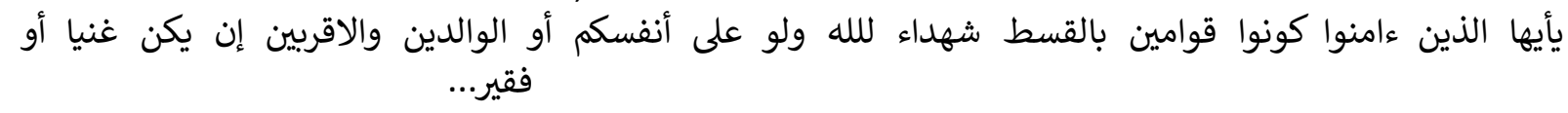

"O you who believe! Stand out firmly for justice as witness to Allah even though it will be against yourself or your parents or your kin, be rich or poor"...(Q4:135)

Shura is acouncil,of learned people upon which khilafa consult for legal advice on matter arising. Allah (S.W.T) direct Prophet Muhammad in the Qur'an thus:

$$
\text { وشاورهم فى الامر.....And consult them in affairs" (Q3:159) }
$$

The Islamic system of governance begins with selection of Khalifa of the state and all other key positions as well as Shura committee. The Shura is responsible for all affairs of the Muslim, they are responsible for decision making. Member of Shura are expected to be a learned, wise, just and person of integrity, they are scholars and leaders in Muslim Community. Shura express the divine will on the basis of the Qur'an stated above. However, Khalifahas no constitutional right to legislate because power of legislation belong to the entire Muslim community or nation most especially where there is no clear evidence from the Qur'an or Hadith on a particular mater (Ali, 2015).

\section{Khalifa}

Khalifa means Successor. It is one person or ruler succeeding the other either by death. AbubakarSidiq happens to be the first Successor of the Prophet after he has passed away in 632 C.E. The Qur'an clearly mentioned that:

$$
\text { وعد الله الذين ءامنوا منكم وعمل الصلحات ليستخلفنهم في الارض.... }
$$

"Allah has promised those among you who believe and do righteous good deeds that he will certainly grant him supersession to (the present rulers) In the land......" (Q24:55)

The Khalifais a representative of Allah on earth to whom people's affairs is entrusted, this is the reason why the Prophet (P.BH) said:

إن المقسطين عند الله علي منابر من نور عن يمين الرحمان عز وجلّ وكل يديه يمين الذين يعدلون في حكمهم وأهليهم وساولوا

"Those who are fair and just will be near to Allah on Throne of Light at the right hand those who are fair and just in their ruling and towards their families and those who are under them" (Muslim Vol.54722) 


\section{Accountability}

Islamic principle of governance involves accountability,every individual are accountable to Allah for their action, accounting for certain things relating to duty and responsibility given to some other with which everyone is accountable. The word "Accountability" often referred to as judgment for whatever action one performed in this world and hereafter.

$$
\text { إقرا كتبك كفى بنفسك اليوم عليك جسيبا }
$$

"(It will be said to him): "Read your book. You yourself are sufficient as a reckoner against you this Day" (Q17:14)

\section{Transparency}

Transparency means openness in transaction. It entails freedom of information, clarity in all public affairs. Transparency in Governance calls for proper documentation and avoidance of default from the transacting parties, the secretary and the witness. It calls for firm information strategies in terms of truthfulness and objectivity and guide against fraudulent act by subjecting every transaction to proper documentation. In this regard Qur'an Says:

يأيها الذين ءامنوا إذا تديتم يدين إلى اجل مسمى فاكتبوه وليكتب بينكم كاتب بالعدل ولا يأب كاتب إن يكتب كما علمه ولئ ولئ



"O you who believe! When you contract a debt for fixed period write it down. Let a scribe write it down in justice between yo. Let not the scribe refuse to write as Allah has taught him, let him write. Let him (the debtor) who incurs the liability dictate and he must fear Allah his Lord and diminish not anything"(Q2:282)

The same verse also laid down the mechanism for preventing act of injustice or fraudulent act as it make sure that every parties involves are being taken care of thus:

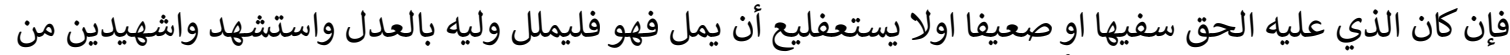

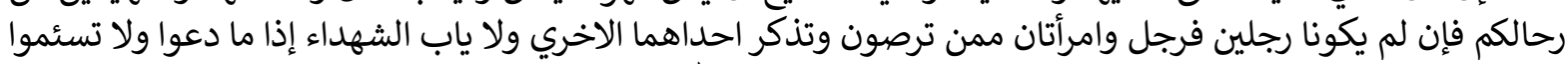

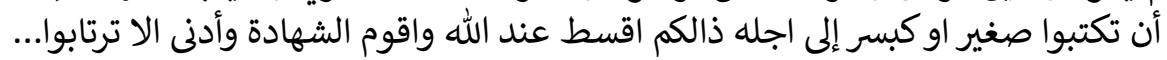
“...But if the debtor is poor of understanding or weak or is unable to dictate for himself then let his guardian dictate in justice. And get two witnesses out of your own men. And if there are not two men (available) then a man and two women such as you agree for witness so that if one of them (two women) errs the other can remind her. And the witnesses should not refuse when they are call (for evidence) you should not become weary to write it (your contract) whether it be small or big for its fixed term, this is more just with Allah more solid as evidence and more convenient to prevent doubt among yourselves..." (Q2:282)

It is important to note that transparency is a foundation upon which good governance stand in every public affair because it allows access to information which to some extent curb misuse of funds or misappropriation or any act of fraudulent. This is the reason why Ayee (2000) stated that transparency gives the citizens the right to available information pertaining to the award of contract, privatization of state enterprise, rules against corruption or funding political parties. Transparency gives room for citizens to search for true information without barrier or the material being charged or presented through misrepresenting mirror. In a situation where transparency is allows it promote fairness in government as it reduce corruption. 


\section{Justice}

Justice means giving every individual citizen equal right or treatment without consideration of one over and above other. It is a situation where by the needs of every member of the society be it social economic, political or otherwise are taken care of. It is a means of distributing wealth in the society with fairness and just. Allah in the Qur'an emphasis justice in every action of the leader where He (S.W.T) says:

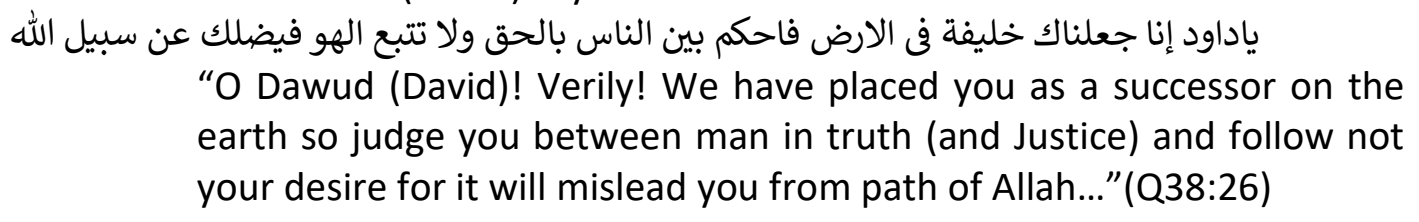

Justice involve equality in every action without favourite, it is exhibition of righteousness in every situation through involvement of morality it does not matter when someone is from one's family or ethnic group, religion or enemy, justice must be cut across every member of the society. In this regard, Allah says:

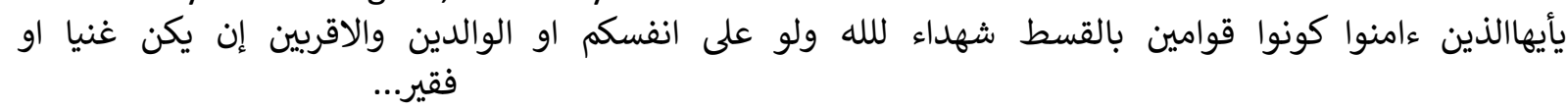

\section{Equity}

The principle of equityin Islamic governance is based on firmness and sincerity, this means that everybody in the society have equal rights and obligation as well as duties and responsibility as citizens. This is done without given privilege to family, ethnic group, rich or poor. The principle of Islamic law is that everybody are equal in the sight of Allah and the most honoured one is the one who exhibit righteousness (piety) in respect of this Qur'an thus:

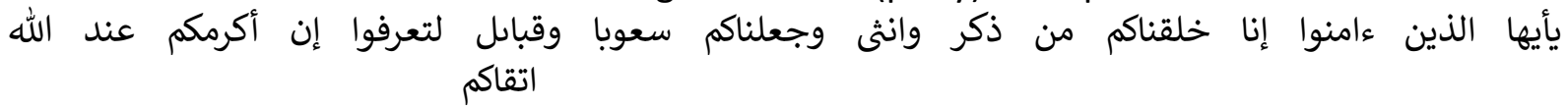

"O mankind! We have created you from a male and female and made you into nations and tribes that you may know one another, Verily, the most honourable of you with Allah is that (believer) who has At-Taqwa (piety)" (Q49:13)

The Islamic principle of governance is not on the basis of race or social status but it is firmly fixed upon piety, justice, equality and equity. It is upon this ground that Ali, 2015 noted that the difference of race, colour or social status are only supplementary and they do not have impact in the true standing of man in the sight of Allah. However, equity is not on the bases of the agreement of noble or giving charity but it is onvalue of trust in which Muslim takes serious and it must be followed with honesty. However, the fundamental Islamic principlesof equality are extremely deep rooted in the organizational settings of Islam which stems from base ideology of the following principles:
a. All men are creature of Allah
b. All mankind originated from Adam and Hawau

c. Allah is just and kind to all His creature and He is not partial to any race, age or religion. The whole universe is His Dominion and all people are created by Him

d. All people are born equally no one comes with any possession into this universe and they shall die equally without returning with any possession 
e. Every mankind are to be judge by Allah on the basis of his merit and according to his deed (Ali, 2015)

$f$. In the sight of Allah the title of honour and dignity is accompanied with piety.

Allah (S.W.T) call for equality and justice among mankind and endowed them with mental ability to exercise their potentiality in the understanding of the rule of law which is the tool for ensuring justice and equality and this is entrust to man that is why Ali (2015) observed that it would be improbable to declare complete equality of human being because there is some degree of similarity in their physical and mental behavior which makes them to understand the rule of law and as well there is a natural range among them in terms of equality and ability to which the rules of law can be interpreted and implemented which of cause might not be the same. However the bottom line is that a leader should make sure he instill justice and equality before the law, use the guidance of the Qur'an and Sunnah.

\section{Al-Amr bi ma'rufwanahi an al-munkar}

It is the responsibility of the leader to command Al-Ma'ruf (good deeds) and discourage Al-Munkar (forbidden things) in this regard Allah Says:

ولتكن منكم امة يدعون الى الخير ويأمرون بالمعروف وينهون عن المنكر وأولئك هم المفلحون

"Let there arise out of you a group of people inviting to all that is good

(Islam), enjoying Al-Ma'ruf (i.e Islamic Monotheism and all that Allah order one to do) and forbidding Al-Munkar (polytheism and disbelief and all that Allah has forbidden). And it is they who are successful"

(Q3:104)

In every society the leader should enjoy his followers to do good and forbade evil. Ordering of good and forbidding evil involves sacrifice in the society because it has to do with jihad principle which need intellectual abilityand collective responsibility of every individual member of the society. It is when people are moving round the good deed and avoid evil that the society would grow and the corruption level would surely reduce.

\section{Conclusion}

In respect of the above a society would not progress when the leaders are corrupt and every measure that might be taken to stop corruption by corrupt leader might not yield if justice and equity is not involved. As a result for this country to move forward, leaders at all level should stand firm to do the right thing and give selfless service rather than selfish and leap service.

\section{Recommendations}

In view of the above, the following are put forward as recommendations:

Muslim Scholars and leaders (Imams) should direct their sermon towards piety, sincerity, truthfulness as they are important and relevant to good governance

The leader should develop act of piety, morality and justice while discharging their duty and responsibility.

The member of the society should charge up with their responsibility in the selection of good leader who will be sincere and work selflessness to achieve the development of the country. Member of the society should be firm and sincere in selecting a leader who has special talent and trained in his field of endeavor so as to be a benefit to the society 
Member of the society should also work tremendously to select God-fearing person who will move for the social solidarity, ethnic harmony and religiously dedicated to the service of Allah (S.W.T)

The leaders in the country most especially the Muslims should imbibe Islamic culture and Islamic principle of consultation to enhance good governance

\section{References}

AbulHussain, M. A (2007) Sahih Muslim.Translated by Nuruddin A. (Huda Khattabeds)

Ali, A. D. (2015) Principle of good governance in Islam.

Http://www.linkedin.com/pulse/principles-good-governace-islam-ali-ahmad-darwish. (retrieved 20/10/2017)

Ali, A. Y. (2007) The Holy Qur'an Translation and commentary. New Delhi India Good word Press

Ayee, J. R. (2000) Making government transparent in Africa: The Ghanian as a case study. CAFRAD, Tangier, Morocco

Chambers. (2004) Chambers universal leaners dictionary (Kirkpatrick. E. M eds) Britain Cox and Wyman Ltd

Chatrurvidi, A. K. (2006) Academic dictionary of political science. New Delhi Academic learner Publisher

Farah, Said, Karim and Edward. (2006) The dictionary Arabic to English Bilingual EnglishArabic with pronunciation transcription. General and scientific dictionary of language and term. Beirut-lebanon, Dar Al-Kotob Al-Ilmiyah Publication

Zainab, Y. (2017) Reflections on administration of Umar BnKhattab as a model for effective governance by contemporary Nigerian leaders in Umar H.D.D and Huud S. (eds) Journal of University Scholar in Religions (JUSREL) Issue 7 P:119

Muhammad, M. K. (1997) Sahih Al-Bukhari, the translation of the meaning of SAhihBukhari Arabic-English. Beirut-Lebanon Dar-al-Arabia Publishing Printing and Distribution

Muhammad, T. A., and Muhammad, M. K. (1404 A.H) The noble Qur'an in English Language. Madinah, Kingdom of Saudi Arabia King Fahd Printing Complex 